\title{
FOGALMI KAPASZKODÓK A KKV-K INNOVÁCIÓS GYAKORLATÁBAN
}

A szerzók cikkükben a hazai innovációfinanszírozási szabályozás alapfogalmi, terminológiai vizsgálatára vonatkozó kutatásaik fố megállapításait mutatják be. Azokat az eredményeket, amelyek elsốsorban a témakör vonatkozó alapismereteinek összegyúijtésére, rendszerezésére irányultak. Vagyis céljuk, az innováció és kapcsolódó fogalmainak áttekintése az alkalmazás szempontjából. Kutatásuk tisztázó jellege iránytúként szolgálhat a gazdasági szakemberek számára, valamint figyelemfelhívásként a jogszabályalkotók felé.

Kulcsszavak: szabályozók, innováció, kutatás-fejlesztés, K+F és I eredmények hasznosítása, termékinnováció, technológiai innováció, eljárásinnováció, szervezeti innováció, szervezési innováció, marketinginnováció

Az innováció az életképes vállalkozások természetes velejárója. Az innovációs folyamat megvalósítása napjaink vállalkozásai számára alapvetô szükséglet. Ma, amikor egyik oldalról nemzetközi kezdeményezések szorgalmazzák az innovációs aktivitás előmozdítását, másik oldalról komoly piaci nyomás tolja a vállalkozásokat az újítások felé, az innovációval foglalkozó szakemberek kérdőjelek erdejével néznek szembe.

Az innovációhoz kapcsolódó fogalomrendszer még nem ágyazódott be teljesen a gazdasági életbe. Az innováció méréséhez és az innovációs tevékenységek értékeléséhez kapcsolódó problémák nehezítik a normatív irányzatok kialakítását. A szerzốk cikkükben a hazai innovációfinanszírozási szabályozás alapfogalmi, terminológiai vizsgálatára vonatkozó kutatásaink fố megállapításait mutatják be. A kutatás elsôsorban a témakör vonatkozó alapismereteinek összegyújjtésére, rendszerezésére irányult, célja az innováció és kapcsolódó fogalmainak áttekintése az alkalmazás szempontjából.

Elôször a vállalatvezetô és -irányító szemével tekintjük át a szakirodalom fogalmait. A következô részek pedig a konkrét innovációs akciók megtervezése és megvalósítása során alkalmazásra kerülő terminológiák tisztázásával foglalkoznak.

\section{Az innováció fogalmi rendszerezése a vállalat- vezetés szempontjából}

$\mathrm{Az}$ innováció fogalomrendszerét a vállalatvezetés szempontjából vizsgálva azt tapasztaljuk, hogy ezek a terminológiák igen sokszínúek, számosak és különböző absztrakciós szinteken megfogalmazottak.

Az innováció meghatározásainak áttekintése során elsősorban a kutatás szempontjából releváns definíciókat kerestük. Ezek elsősorban azok, amelyek egy kisés közepes méretû vállalkozás számára kézzelfogható módon adnak útmutatást az innovációs tevékenységük gyakorlásához. A kkv-k jellemzőire és innovációs sajátosságaira ehelyütt nem térünk ki.

A kutatás e szakaszában az innovációértelmezés különbözô szintjeit azonosítottuk. A szintek értelmezését az innováció konkrét gyakorlati megvalósításához kötöttük. Azt vizsgáltuk, hogy a döntéshozatal és a megvalósítás során az innovációt meghatározó fogalmak alkalmazására mikor, hol, milyen körülmények között és kinek célszerú sort keríteni. A szakirodalmi kutatások és a vállalatvezetési gyakorlat illesztését figyelembe véve az alábbi kategóriák bevezetését javasoljuk:

- szemléletformáló,

- értelmezési célú,

- megvalósítás célú innovációterminológiákat.

A következókben bemutatjuk az egyes kategóriákat, azok jellemzóit, valamint példákkal támasztjuk alá állításainkat.

Az innováció fogalmainak e csoportosítása navigációs célú. A vezetố szakemberek számára valamennyi fogalom információval bír a mindenkori döntési pontokban és szituációkban. 


\section{Szemléletformáló innovációmeghatározások}

Az innovációt érintô paradigmaváltások elsô hírnökei közé tartozónak ítéljük azokat a meghatározásokat, amelyek új irányokat jelölnek ki az innováció értelmezésében. Ezek szemléletformáló jelentőségúek, hatásuk stratégiai horderejú, mert átalakítja az innovációról alkotott fogalmainkat, látásmódunkat. Teljesen megváltoztatja az innovációs tevékenység környezeti beágyazottságát, kapcsolati struktúráját, átalakítva ezzel eszközrendszerét.

Ide sorolhatók például Schumpeter (1939), Drucker (2003) vagy Prahalad (2009) innovációfogalmai.

J. A. Schumpeter (1939) az innováció lényegét a termelési tényezôk új kombinációjában jelölte meg. Felfogása minden további innovációval foglalkozó elmélet kiindulópontjának tekinthetô. Schumpeter az innováció öt alapesetét különböztette meg a következóképpen:

- új - tehát a fogyasztók körében még nem ismert - javaknak, vagy egyes, már létezó javaknak új minőségben való előállítása,

- új, tehát a kérdéses iparágban még gyakorlatilag ismeretlen termelési eljárás bevezetése, amelynek azonban semmiképpen sem kell új tudományos felfedezésen alapulnia, valamely áruval kapcsolatos új kereskedelmi eljárás is lehet,

- új elhelyezési lehetôség, vagyis olyan piac megnyitása, amelyen a kérdéses ország iparága ez ideig nem volt jelen akár létezett a piac korábban, akár nem,

- nyersanyagok vagy félkész áruk új beszerzési forrásainak megnyitása, mindegy, hogy ez a beszerzési forrás korábban is létezett, csupán nem vették figyelembe, illetve nem tartották megfelelónek, vagy pedig először kellett kialakítani,

- a feladatokhoz jobban illeszkedố új szervezet kialakítása.

Drucker (2003) szerint: ,az innováció a vállalkozás gazdasági vagy társadalmi lehetőségeinek céltudatos, koncentrált megváltoztatására irányuló erőfeszítés."

C. K. Prahalad (2009) szerint: „Az innováció következô formáinak a termékek és a szolgáltatások helyett - a vállalatok és fogyasztói közösségek hálózatának támogatásával - a tapasztalati környezetre kell összpontosítaniuk, amelynek célja, hogy az egyes fogyasztókkal együtt teremtsenek egyedi értéket."

\section{Értelmezési célú, tisztázó jellegü innovációmeghatározások}

$\mathrm{Az}$ innováció konkrét tartalmi elemeit számba vevô, a megértést segítô, a fogalom könnyebb diffúzióját szolgáló meghatározások és definíciók. Adott paradigmán belül mutatják be az innováció fớbb jellegzetességeit. Rendszerező jelleggel veszik számba az innováció tartalmi elemeit. Útmutatásul szolgálnak az innováció fogalmának értelmezésében. Segítik az innováció megismerését és kivitelezését, valamint feltárják az innováció tevékenységei között rejlő összefüggéseket. Bemutatják és érzékeltetik az innovációs folyamat jellegzetességeit és összegzik annak lépéseit.

Úgy ítéljük meg, hogy az alábbi fogalmak ebbe a kategóriába sorolhatók.

Pietrasinszky (1970): „Azt a változást, amelyet az ember vagy a rendszer azzal a céllal vezet be, hogy az adott állapotot új állapotok váltsák fel, feltéve, hogy az utóbbiak bizonyos ismérvek szerint pozitívan értékelendók és a maguk összességében haladást jelentenek."

Pál (1981): „Szúkebb értelemben innováción a gyártmány és gyártás (termékek és technológia) olyan minőségi fejlesztését értjük, amely gazdasági hasznot hozó újszerúségek létrehozását eredményezi. Ez a minôségi fejlesztés egyidejúleg hatja át a kutatás, fejlesztés, termelés és fogyasztás szféráit. Így az innováció, mint összekötô, kölcsönhatásokat közvetítő folyamat jelenik meg, amelynek hatásai a kutatás-fejlesztés-értékesítés láncolat valamennyi láncszemében érezhetók."

Pearce (szerk.) (1993): „Innovációnak tekintik a termelési folyamatban bevezetett technológiai fejlesztéseket és a piacképes termékek különböző tulajdonságainak és e tulajdonságok kombinációinak bevezetését. Az utóbbi a termékdifferenciálás forrása és a termelók a kereslet generálására, piaci részesedésük növelésére használják fel."

Freeman innovációs elmélete (1988): alapján Buzás (2007) az alábbi négy kategóriát használja az egyes innovációs folyamatok megkülönböztetésére:

- fokozatos vagy módosító innovációk, amelyek nem érintik a megoldás alapelveit, hanem csak kisebb módosításokat eszközölnek azok változatlanul hagyása mellett, eredményképpen többnyire hatékonyságjavulást tapasztalunk, amely minőségjavítás, költségcsökkenés vagy teljesítménynövelés formát ölt,

- radikális innovációk, amely során a korábbi hagyományokkal való szakítás után új termék születik akár a régi, vagy új technológiára alapozva,

- termelésieljárás-változások, amelyek során a korábban alkalmazott technológiákat gondolják újra,

- paradigmaváltások, amelyek az uralkodó technológiai nézópont megváltozását jelentik.

Trott (2005): szerint „Az innováció részét képezi az új és újszerú megoldások kialakítása - vagyis a feltalálás -, ugyanakkor a tevékenység kiegészül annak üzleti célú megvalósításával."

\section{VEZETÉSTUDOMÁNY}


Az innováció típusai Szakály szerint

\begin{tabular}{|l|l|}
\hline \multicolumn{1}{|c|}{ típusa } & \multicolumn{1}{c|}{ tartalma } \\
\hline $\begin{array}{l}\text { 1. TERMÉKINNOVÁCIÓ } \\
\text { - újítás a vállalat értékesíthető teljesítményeiben. }\end{array}$ & $\begin{array}{l}\text { A termékinnováció olyan áru vagy szolgáltatás bevezetése, } \\
\text { amely - annak tulajdonsága és rendeltetése vonatkozásában - } \\
\text { új vagy jelentôsen megújított.Ez magában foglalja a fejlesztésre } \\
\text { vonatkozó részletes múszaki leírásokat, az összetevóket és } \\
\text { anyagokat, a beépített szoftvert, a felhasználóbarát jelleget vagy } \\
\text { más funkcionális tulajdonságokat. }\end{array}$ \\
\hline $\begin{array}{l}\text { 2. FOLYAMAT-(ELJÁRÁS) INNOVÁCIÓ } \\
\text { - újítások a produktum létrehozásának anyagi és irányítási } \\
\text { folyamataiban, beleértve a módszertani változtatásokat is. }\end{array}$ & $\begin{array}{l}\text { Az eljárásinnováció új vagy jelentósen megújított termelési vagy } \\
\text { szállítási módszer megvalósítása.Felöleli a technikában, a berende- } \\
\text { zésekben és/ vagy a szoftverben bekövetkezó jelentós változásokat. }\end{array}$ \\
\hline $\begin{array}{l}\text { 3. MARKETINGINNOVÁCIÓ } \\
\text { - újítások a marketing-módszerekben, } \\
\text { - újítások a fogyasztói szükségletek és a piacok kezelésében. }\end{array}$ & $\begin{array}{l}\text { A marketinginnováció olyan marketingmódszerek alkalmazása, } \\
\text { amelyek jelentós változást hoznak a terméktervezésben, a csoma- } \\
\text { golásban, a termék piacra dobásában, a termék reklámozásában } \\
\text { vagy az árképzésben. }\end{array}$ \\
\hline $\begin{array}{l}\text { 4. STRUKTURÁLIS (SZERVEZÉSI-SZERVEZETI) } \\
\text { INNOVÁCIÓ } \\
\text { - újítások az üzleti gyakorlatban- újítások a } \\
\text { menedzsmentrendszerekben. }\end{array}$ & $\begin{array}{l}\text { A szervezési-szervezeti innováció új menedzsmentmódszerek } \\
\text { megvalósítását jelenti a cég üzleti gyakorlatában, a munka szer- } \\
\text { vezésében vagy a külsố kapcsolatokban. }\end{array}$ \\
\hline
\end{tabular}

Katona (2006) ismertetése alapján Szakály (2008) az innováció típusait és tartalmát az 1. táblázatban foglalta össze.

\section{A megvalósítást támogató innováció meghatározások}

A gyakorlati megvalósítás, kivitelezés szempontjából a következő kategória a gyakorlat számára alapvető fontosságú innovációmegfogalmazásokat tartalmazza. E definíciók támogatják a stratégiaalkotást és lehetôvé teszik az operatív tervezést, mivel konkrét elő́rásokat fogalmaznak meg a gyakorlati megvalósíthatóságra. Alkalmazásukkal nemcsak az innovációs tevékenységek tervezése válik lehetségessé, hanem az innováció gyakorlati kivitelezése, finanszírozása, elszámolhatósága is.

Ebbe a kategóriába soroljuk mindazokat a meghatározásokat, amelyek a különböző tervezési, pályázati, pénzügyi, számviteli, adózási tevékenységek fogalmi, értelmezési hátterét biztosítják.

Ebbe a kategóriába soroljuk például az Oslo Kézikönyv, a Frascati Kéziköny, a 2004/CXXXIV. a kutatás-fejlesztésról és a technológiai innovációról szóló törvény, valamint a számviteli és az adótörvény innovációra vonatkozó meghatározásait, előírásait. Ide tartozónak tekintjük a pályázati kírások által megfogalmazott innovációt és annak tevékenységeihez kapcsolódó terminológiákat is. Összességében ide tartoznak azok a meghatározások, amelyeket a különböző szabályzókban rögzítettek abból a célból, hogy az innovációs tevékenységekre vonatkozó fogalmakat egyértelmúsítsék.
(Forrás: Szakály, (2008))

OECD Oslo-Kézikönyv (2000) „Az innováció mindazon tudományos, múszaki, kereskedelmi és pénzügyi tevékenységek együttese (egy ötlet átalakulása, újfajta megközelítése), amelyek új termékek kifejlesztéséhez és értékesítéséhez, új termelési eljárások, vagy berendezések hasznosításához, vagy valamely társadalmi szolgáltatás új megközelítésének bevezetéséhez szükségesek."

A Frascati Kézikönyv - amely az innováció mérésére vonatkozó ismereteket tartalmazza - (OECD, 2003) szerint: ,,a múszaki innováció olyan tudományos, múszaki, szervezeti, pénzügyi és kereskedelmi jellegú tevékenység - ideértve az új ismeretanyagba történó befektetést is -, amely ténylegesen, vagy szándék szerint technikailag tovább fejlesztett termékek és eljárások megvalósításához vezet. A K+F egyike e tevékenységi körnek - az innovációs folyamat bármelyik szakaszában."

Az Oslo Kézikönyv 2005. évi 3. kiadása szerint: „Az innováció új vagy jelentôsen javított termék (áru vagy szolgáltatás) vagy eljárás, új marketingmódszer vagy új szervezési-szervezeti módszer bevezetése az üzleti gyakorlatban, munkahelyi szervezetben vagy a külső kapcsolatokban."

Ezek azok a definíciók, amelyek a jelen kutatás szempontjából alapvető fontosságúnak tekinthetőek. Ismeretük a gyakorló szakemberek számára nélkülözhetetlen a sikeres innováció megvalósításához. 


\section{Az innováció és a kutatás-fejlesztés kapcsolata}

Az innováció fogalomköreinek érintésekor nem hagyhatjuk figyelmen kívül az innováció és a $\mathrm{K}+\mathrm{F}$ kapcsolódásait. Ugyanis a fogalmak tartalmi összefonódása egyre inkább tetten érhetô a gyakorlatban.

\section{A témakör általános ismeretei}

$\mathrm{Az}$ elôzőekben körüljártuk az innováció fogalmának különbözô csoportjait. Célszerúnek látjuk kiemelni azt, hogy a $\mathrm{K}+\mathrm{F}$ tevékenység nem azonos az innovációval. Tény, hogy a két fogalom több ponton is egyezôséget mutat, mégis hiba lenne szinonimaként kezelni ôket. A két fogalom viszonyát az 1. ábra is jól érzékelteti.

\section{Az innováció és a K+F közötti kapcsolat}

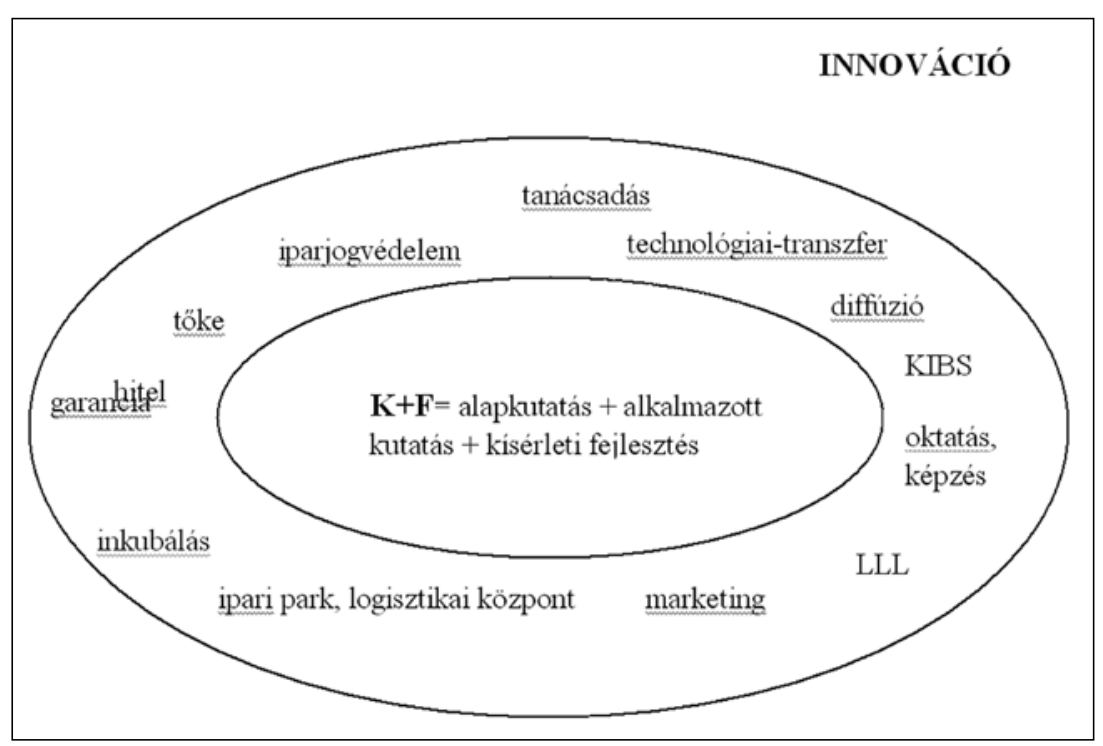

Röviden összefoglalva azt mondhatjuk, hogy minden $\mathrm{K}+\mathrm{F}$ innováció, de nem minden innováció számít $\mathrm{K}+\mathrm{F}-\mathrm{nek}$. A kutatás-fejlesztés az innovációs tevékenység lényege, kemény magja. $\mathrm{A} \mathrm{K}+\mathrm{F}$ elsô, alapvetô feladata - vagyis az alapkutatás -, fóként a kutatóintézetekben és a felsôoktatási kutatóhelyeken zajlik. A kísérleti fejlesztésekre leginkább a vállalkozások keretein belül kerül sor. Az alkalmazott kutatás egyaránt megjelenik a kutatóintézetekben és a felsőoktatási kutatóhelyeken, valamint a vállalkozásokban. Ugyanakkor ahhoz, hogy a kutatás-fejlesztés eredménye új alkalmazásokban jelenjen meg egyéb innovációs tevékenység is szükséges: a tervezés, az engineering, a gyártás megindítása, a marketing, vagy például a licencvásárlás. Az innováció a $\mathrm{K}+\mathrm{F}$ kiadásokon keresztül ragadható meg számszerúségében, miközben tudjuk, hogy az innováció több ennél szellemi és anya- gi ráfordításokban egyaránt. Az innovációs folyamat tehát egyre kevésbé korlátozódik a know-how vagyon fejlesztésére. Egyre fontosabb szerepet kap a K+F-en túli tudás. Amennyiben az 1. ábrát vesszük alapul, nyugodtan kijelenthetjük, hogy a vállalkozások innovációs tevékenysége keretében ezen elemek önmagukban történô megújítása, a közöttük lévő kapcsolati rendszer fejlesztése és átalakítása, a preferenciák módosítása mind-mind innovációnak tekinthetô. Látható, hogy a $\mathrm{K}+\mathrm{F}$ ebben a felfogásban az innovációs tevékenység csupán egyik - noha meghatározó - eleme (Iványi - Hoffer, 2011).

\section{Az innováció és a $K+F$ fogalmi szabályozottsá- gának gazdasági következményei}

1. ábra Az innováció definícióira vonatkozó témakör vizsgálata nem csupán elvi jelentôségú. Hordereje messze túlmutat az elméleti kutatók szakmai dilemmáin. A definíciók a nemzeti innovációs rendszer egyértelmú kommunikációját és kezelését biztosítják. Konzisztenciájuk az alábbiak miatt szükségszerú (Balogh, 2009):

- a statisztikai adatok megbízhatósága (KSH, EUROSTAT stb.),

- a K+F adókedvezmények megítélése (jogszabályi előírások a számviteli és adótörvényben),

- az EU állami támogatási szabályainak betartása,

- a szakpolitikák megbízható és nemzetközileg is összehasonlítható bázisának megteremtése (2. táblázat).

2. táblázat

Eltérések és azonosságok az innováció és $\mathrm{K}+\mathrm{F}$ szabályozottsága vonatkozásában

\begin{tabular}{|c|c|}
\hline \multicolumn{2}{|c|}{$\begin{array}{c}\text { Eltérések és azonosságok az innováció } \\
\text { és } K+F \text { vonatkozásában }\end{array}$} \\
\hline van & nincs \\
\hline $\begin{array}{l}\text { - pontos } \mathrm{K}+\mathrm{F} \text { definíció } \\
\text { - } \mathrm{K}+\mathrm{F} \text { statisztika } \\
\text { - } \mathrm{K}+\mathrm{F} \text { adókedvezmény } \\
\text { - } \mathrm{K}+\mathrm{F} \text { állami támogatási } \\
\text { szabályozás }\end{array}$ & $\begin{array}{l}\text { - pontos és egyértelmúen elfogadot } \\
\text { innovációs definíció (mert az Oslo } \\
\text { Kézikönyvben foglaltak sem ke- } \\
\text { rültek teljeskörúen elfogadásra) } \\
\text { - egyértelmú innovációs statisztika } \\
\text { - innovációs adókedvezmény } \\
\text { - innovációs állami támogatási sza- } \\
\text { bályozás }\end{array}$ \\
\hline
\end{tabular}


Az innováció $\mathrm{K}+\mathrm{F}$-en túli tevékenységei feltétlenül szükségesek az innovatív technológiák és módszerek alkalmazásához, piacra történő eljuttatásához és integrálásához.

Az innováció tehát a kutatási eredmények gyakorlati alkalmazásának is tekinthetô. Jól elhatárolható a kutatás-fejlesztés tevékenységétól. A kutatás-fejlesztés és az azt követő innovációs lépések közötti jelentős eltérés, hogy az utóbbiak nagyságrendekkel több anyagi befektetést igényelnek. A kutatási-fejlesztési fázis ugyan nagyfokú kockázatot rejt magában, de az azt követô innovációs lépésekhez viszonyítva szerényebb ráfordítást igényel. Az innováció ebben a felfogásban egyrészt a termelókapacitás létesítését, másrészt a piacra jutással, értékesítéssel kapcsolatos feladatokat tartalmazza, és azok ráfordításait jelenti (Tarnói, 1997).

Az innováció és a $\mathrm{K}+\mathrm{F}$ közötti különbségtételnek a kkv-k esetében is nagy jelentőséget tulajdonítunk. Ugyanis mint láttuk, a társaságok innovációs aktivitása nem azonos a statisztikák által kimutatott jellemzókkel. Az innovatív megoldások keresése és alkalmazása közvetlenül nem jelenik meg a mutatószámokban, viszont jellemzi a vállalkozások gyakorlatát. A hazai kkv-szektor vezetố szakemberei számára az innovációhoz kötődő fogalmak ismerete és használata szükséges a potenciális fejlesztési források eléréséhez.

\section{Az innováció fogalomköreinek áttekintő vizsgálata a gyakorlati megvalósítás szempontjából}

A következôkben bemutatjuk mindazon kutatási eredményeinket, amelyek feltárják a jelenleg hatályos szabályozók innovációs fogalomköreiben tapasztalható sajátosságokat.

\section{A kutatási terv vázlata}

A kutatás lépései az alábbiakban nevesíthetók:

- a kkv-k innovációs gyakorlatát alapvetően meghatározó szabályozók kiválasztása,

- a kutatás szempontjából releváns fogalmak kijelölése,

- a fogalmi gyújtés és rendszerezés elvégzése,

- a következtetések levonása.

\section{A szabályzók kiválasztása és a fogalmak kijelölése}

A kutatás elókészítése során úgy ítéltük meg, hogy a vállalati „tervezés - forrásteremtés - megvalósítás - elszámolás - elemzés" leegyszerúsített folyamatát tekintjük mértékadónak, ügyelve arra, hogy az innovációmenedzsmenttel összefüggésbe hozható valamennyi meghatározó vállalati tevékenységet lefedjük.
Ennek megfelelóen az alábbi öt fó szabályozó áttekintését végeztük el a fogalmak vizsgálata céljából:

- a 2004/CXXXIV. a kutatás-fejlesztésról és a technológiai innovációról szóló törvény,

- a Nemzeti Innovációs Hivatal (NIH) Fogalomtára,

- a KTI ALAP TAMOK 146/2007. rendelet (vagyis a 146/2007. (VI. 26.) Kormányrendelet a Kutatási és Technológiai Innovációs Alapból nyújtott állami támogatások szabályairól),

- a KSH-adatbázishoz használt fogalomtár, valamint

- a 2000. évi C. törvény a számvitelról vonatkozó előírásairól.

\section{Az innováció fogalomkörei a szabályozókban}

Legelőször arra kerestünk választ, hogy az adott szabályozó definiálja-e az általunk relevánsnak tartott fogalmat, és ha igen, hogyan. Az eredményeinket táblázatos formában jelenítjük meg. A definíciós összegző tábla tehát az általunk relevánsnak tekintett fogalmak szabályozókban történő meghatározottságát mutatja.

A kiválasztott fogalmak csoportosítása az alábbiak szerint történt.

- tevékenység,

- szervezet,

- a program jellege,

- forrásjellemzók,

- humán vonatkozások.

E kategóriákat egy vállalkozás múködése során felmerülő tevékenységek mentén alakítottuk ki (3. táblázat).

A fenti gyújtés csupán arról ad felvilágosítást, hogy az általunk kiválasztott és a kutatás szempontjából fontosnak ítélt fogalmak az egyes szabályozók által definiálva vannak-e vagy sem. A 3. táblázatból nem derül ki, hogy ezek a fogalmak miképp, milyen módon szerepelnek az egyes szabályozókban. Erre csak a részletes fogalmi meghatározások kigyuujtése és rendszerezése ad választ.

A definíciós összegző táblázat információt azonban önmagukban is érdemes áttekinteni. A táblázat ugyanis számos érdekes momentumra irányítja a figyelmünket. Ezek összegzése során jelen cikkünkben nem élünk a priorizálás lehetôségével, sem az egyes megállapítások magyarázó értékelésével. Következtetéseinket röviden fogalmazzuk meg, miközben eltekintünk az egyes gazdasági szereplókre gyakorolt hatások értékelésétól.

- Az eltéró területeken alkalmazott jogszabályok és rendeletek célja a hazai innovációs törekvések támogatása. Az egyes szabályozók az innovációs gyakor- 
Definíciós összegző tábla

\begin{tabular}{|c|c|c|c|c|c|}
\hline Definíciók & 言紊 & 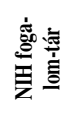 & 稿 & 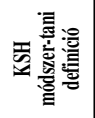 & 竞: \\
\hline \multicolumn{6}{|c|}{ TEVÉKENYSÉG } \\
\hline Innováció & - & $\mathrm{X}$ & $\mathrm{X}$ & $\mathrm{X}$ & - \\
\hline Alapkutatás & $\mathrm{X}$ & $\mathrm{X}$ & $\mathrm{X}$ & $\mathrm{X}$ & $\mathrm{X}$ \\
\hline Tiszta alapkutatás & $\mathrm{X}$ & $\mathrm{X}$ & $\mathrm{X}$ & $\mathrm{X}$ & - \\
\hline Célzott alapkutatás & $\mathrm{X}$ & $\mathrm{X}$ & - & $\mathrm{X}$ & - \\
\hline Kutatás-fejlesztés & $\mathrm{X}$ & $\mathrm{X}$ & $\mathrm{X}$ & $\mathrm{X}$ & - \\
\hline Ipari vagy alkalmazott kutatás & $\mathrm{X}$ & $\mathrm{X}$ & $\mathrm{X}$ & $\mathrm{X}$ & $\mathrm{X}$ \\
\hline Kísérleti (prekompetitív fejlesztés) & $\mathrm{X}$ & $\mathrm{X}$ & $X$ & $\mathrm{X}$ & $\mathrm{X}$ \\
\hline K+F és I eredmények hasznosítása & $\mathrm{X}$ & $\mathrm{X}$ & - & - & - \\
\hline Termék- (áru- vagy szolgáltatás) innováció & - & $\mathrm{X}$ & $\mathrm{X}$ & $\mathrm{X}$ & - \\
\hline Technológiai innováció & $\mathrm{X}$ & $\mathrm{X}$ & $\mathrm{X}$ & - & - \\
\hline Eljárásinnováció & - & $\mathrm{X}$ & $\mathrm{X}$ & $\mathrm{X}$ & - \\
\hline Szervezeti innováció & $\mathrm{X}$ & $\mathrm{X}$ & - & $\mathrm{X}$ & - \\
\hline Szervezési innováció & - & $\mathrm{X}$ & $\mathrm{X}$ & $\mathrm{X}$ & - \\
\hline Marketinginnováció & - & $\mathrm{X}$ & - & $\mathrm{X}$ & - \\
\hline \multicolumn{6}{|l|}{ SZERVEZET } \\
\hline Innovatív szervezet & - & - & $\mathrm{X}$ & $\mathrm{X}$ & - \\
\hline Innovációs klaszter & - & $\mathrm{X}$ & $\mathrm{X}$ & - & - \\
\hline Költségvetési kutatóhely & $X$ & $\mathrm{X}$ & - & - & - \\
\hline Nonprofit kutatóhely & $X$ & $X$ & - & - & $X$ \\
\hline Kutatóhely & $\mathrm{X}$ & $\mathrm{X}$ & - & - & - \\
\hline Kutatási szervezet & - & - & $\mathrm{X}$ & - & - \\
\hline Civil szervezet & $\mathrm{X}$ & $\mathrm{X}$ & - & - & - \\
\hline Hasznosító vállalkozás & $\mathrm{X}$ & $\mathrm{X}$ & - & - & - \\
\hline $\mathrm{Kkv}$ & - & $\mathrm{X}$ & $\mathrm{X}$ & - & - \\
\hline Kkv, mint kutatóhely & - & - & - & $X$ & - \\
\hline \multicolumn{6}{|c|}{ PROGRAM JELLEGE } \\
\hline Kutatás-fejlesztési és technológiai innovációs program & $\mathrm{X}$ & $\mathrm{X}$ & - & - & - \\
\hline Projekt & $\mathrm{X}$ & $\mathrm{X}$ & $\mathrm{X}$ & - & - \\
\hline $\mathrm{K}+\mathrm{F}$ projekttámogatás & - & - & $\mathrm{X}$ & & \\
\hline Innovációs projekt & - & - & - & - & - \\
\hline Kutatás-fejlesztési beruházás & - & - & - & $\mathrm{X}$ & - \\
\hline Beruházás & - & $\mathrm{X}$ & - & - & $\mathrm{X}$ \\
\hline Nagyberuházás & - & $\mathrm{X}$ & $\mathrm{X}$ & - & - \\
\hline Induló beruházás & - & - & $\mathrm{X}$ & - & - \\
\hline \multicolumn{6}{|c|}{ FORRÁS JELLEMZŐ } \\
\hline Saját forrás & - & $\mathrm{X}$ & $\mathrm{X}$ & - & - \\
\hline Támogatástartalom & - & - & $\mathrm{X}$ & - & - \\
\hline Beruházási támogatás & - & $\mathrm{X}$ & $\mathrm{X}$ & - & - \\
\hline Állami támogatás & $\mathrm{X}$ & $\mathrm{X}$ & $\mathrm{X}$ & - & - \\
\hline Közfinanszírozású támogatás & $\mathrm{X}$ & $\mathrm{X}$ & $\mathrm{X}$ & - & - \\
\hline Ösztönző hatású támogatás & - & - & $\mathrm{X}$ & - & - \\
\hline \multicolumn{6}{|c|}{ HUMÁN VONATKOZÁSOK } \\
\hline Magasan képzett munkaerô & - & $\mathrm{X}$ & $\mathrm{X}$ & - & - \\
\hline Kutató-fejlesztő & $\mathrm{X}$ & $\mathrm{X}$ & - & $\mathrm{X}$ & - \\
\hline Speciális képzés & - & - & $\mathrm{X}$ & - & - \\
\hline
\end{tabular}

(Forrás: saját szerkesztés) lat különböző aspektusait hivatottak szabályozni. Ezért a gazdálkodás különbözó területeit eltérô módon kapcsolják be a fogalomhasználaton keresztül.

- Az egyes szabályozó elemeket eltérô időpontokban fogalmazták meg, és léptek azok életbe, így különbözó „korok”, időszakok lenyomatait hordozzák magukon. Naprakészségük eltérő szintü.

- A 2004/CXXXIV. törvény a kutatás-fejlesztésrôl és a technológiai innovációról nem definiálja az innovációt, miközben a megjelenési formáit tartalmazza. A törvényalkotó szempontjából minderre tudatosan került sor, az innováció szerteágazó, és kívülrôl gyakorlatilag lehatárolhatatlan természete okán. Ugyanakkor a törvényben a ,technológiai innováció" fogalmának bevezetése jelentős mértékben bôvítette ki a kutatás-fejlesztésen túli innovációk mozgásterét.

- Figyelemre méltó, hogy a hagyományos értelemben vett $\mathrm{K}+\mathrm{F}$-en túli innováció amelynek kiemelt figyelmet szenteltünk cikkünkben -, egyre meghatározóbb módon van jelen a szabályozásban.

- A táblázatból egyértelmúen kiderül, hogy az innováció megjelenési formái - a nemzetközi gyakorlatot követve - ma már jelen vannak az innováció ösztönzését és számbavételét támogató szabályzókban egyaránt. Ez látható a termék-, a technológiai, az eljárás-, a szervezeti, a szervezési, valamint a marketinginnovációk fogalmi használatából. 
- Nagyon jól érzékelhető, hogy az ösztönzók, valamint a pályázati lehetőségek által megerósített innovációs területek teret nyertek, és egyre markánsabban jelennek meg a szabályozásban.

- A táblázat jelzi, hogy a számviteli törvény fogalmi szinten sem követte a területen végbemenő lényeges változásokat. Az elszámolás szigorú rendszerébe sem az innováció új megjelenési formái, sem pedig a $\mathrm{K}+\mathrm{F}$-en túli innovációk illesztésére nem került sor. Ennek magyarázó indoka a konkrét tételek elszámolhatósági kritériumaival függ össze, amelynek gyakorlati megvalósíthatósága számos kérdést vet fel.

- Számviteli oldalról ma még mindig a klasszikus értelemben vett $\mathrm{K}+\mathrm{F}$, valamint az azokat megvalósító beruházások jelennek meg az innováció meghatározó jellemzóiként. Ez a körülmény is hozzájárul ahhoz, hogy a gyakorló szakemberek esetenként csakis a $\mathrm{K}+\mathrm{F}$-et tekintik innovációs tevékenységnek.

- A szervezeti, szervezési, vagy akár a marketinginnovációk csakis a közvetlenül kapcsolódó beruházásaikon keresztuil tekinthetók számviteli szempontból innovációnak.

- Figyelemre méltó, hogy a számviteli törvény nem nyújt kapcsolódási felületet a saját forrás, a támogatástartalom, a beruházási támogatás, az állami támogatás, a közfinanszírozású támogatás, az ösztönző hatású támogatás fogalmainak.

- A KSH szervezetektôl történő adatkérései elsôsorban az innováció megjelenési formáit kutatják. A jelentésre kötelezett szervezetek a kitöltés során többnyire a számviteli rendszer által meghatározott adatokra építhetnek. Ezek azonban direkt módon nem feleltethetốk meg a KSH által elvárt csoportosítás kategóriáinak.

- A KSH fogalomtára nem terjed ki az innováló szervezettel kapcsolatos kérdésekre. Ez természetes, hisz a KSH-jelentés beküldésekor a szervezet jellemzóit eleve kitöltik, a KSH a szervezeti egységet a saját rendszere alapján azonosítja.

- A kutatást és hasznosítást folytató „,szervezet” meghatározására számos pontosítást, szabályozást találunk. Ezek a kategóriák nem jelennek meg a KSH és a számviteli törvény keretein belül.

- A ,program jellege”-t vizsgálva úgy túnik, hogy ez a tényező nem tekinthetô elsődlegesnek a szabályalkotók szempontjából.
- Mindenképpen elgondolkodtató, hogy az innováció forrásokkal kapcsolatos terminológiái közül egy sem lelhetô fel a számviteli törvény sorai között.

Megállapításainkat az áttekintô táblázat információira, valamint saját és gyakorló vezetố kollégák szakmai tapasztalataira építve tettük meg. Úgy ítéljük meg, hogy a pontosabb és konkrétabb következtetések levonásához a 3. összegzô táblázat egyes sorainak kibontására és elemzésére van szükség. Ezzel a következőkben foglalkozunk.

\section{Az innováció, mint „tevékenység” fogalmainak áttekintése}

Cikkünkben csupán általunk az innováció, mint tevékenység fogalomkörébe sorolt meghatározásokat tekintjük át.

A „Tevékenység” témakörében a következő fogalmak meghatározásait gyưjiöttük össze (4. táblázat).

4. táblázat

\section{Az innováció vizsgált „tevékenység” fogalmai}

\begin{tabular}{|l|l|l|}
\hline \multicolumn{1}{|c|}{ Innováció } & \multicolumn{1}{c|}{ Ipari vagy alkalmazott kutatás } & \multicolumn{1}{c|}{ Eljárás innováció } \\
\hline Alapkutatás & Kísérleti (prekompetetív fejlesztés) & Szervezeti innováció \\
\hline Tiszta alapkutatás & K+F és I eredmények hasznosítása & Szervezési innováció \\
\hline Célzott alapkutatás & Termék (áru vagy szolgáltatás) innováció & Marketinginnováció \\
\hline Kutatás-fejlesztés & Technológiai innováció & \\
\hline
\end{tabular}

(Forrás: saját szerkesztés)

A következókben csupán néhány, a mondanivalónk szempontjából figyelemre méltó táblázatot mutatunk be. Valamennyi fogalomhoz tartozó összegzô táblázat feltüntetésére terjedelmi okokból sem kerülhetett sor (5. táblázat).

A 2004/CXXXIV. a kutatás-fejlesztésról és a technológiai innovációról szóló törvény az innováció témakörébe tartozó meghatározások közül csaknem mindre kitér.

Látható, hogy a számviteli törvény sem foglalja magába az innováció meghatározását. Itt a számviteli gyakorlatban szükséges meghatározások kerülnek elôtérbe és definiálásra (6. táblázat).

A kutatás-fejlesztés fogalmainak gyújtését követô rendszerezésnél azt tapasztaltuk, hogy a vonatkozó szabályozás azonos fogalmi körökkel operál. Ez alól kivételt a számviteli törvény képez. Ez utóbbit azért is érdemes megemlíteni, mivel a $\mathrm{K}+\mathrm{F}$ és az Innováció viszonyának értelmezése nagy jelentôséggel bír.

A KSH definíció a $\mathrm{K}+\mathrm{F}$ tartalmi elemeinek felsorolásán kívül magyarázó értelmezést is tartalmaz ( 7. táblázat). 
Az innováció fogalmai

\section{INNOVÁCIÓ}

\begin{tabular}{|l|l|}
\hline \multicolumn{2}{|c|}{ INNOVÁCIÓ } \\
\hline $\begin{array}{l}\text { 2004/CXXXIV. törvény } \\
\text { a kutatás-fejlesztésról és a } \\
\text { technológiai innovációról }\end{array}$ & Nem definiálja külön az innováció fogalmát. \\
\hline NIH fogalomtár & $\begin{array}{l}\text { Új vagy jelentósen javított termék (áru vagy szolgáltatás) vagy eljárás, új marketingmódszer vagy új } \\
\text { szervezési-szervezeti módszer bevezetése az üzleti gyakorlatban, munkahelyi szervezetben vagy a } \\
\text { külső kapcsolatokban. }\end{array}$ \\
\hline $\begin{array}{l}\text { KTI ALAP támok, } \\
\mathbf{1 4 6 / 2 0 0 7} \text { rendelet }\end{array}$ & Magában foglalja a technológiai, az eljárási és a szervezési innovációt. \\
\hline $\begin{array}{l}\text { KSH módszertani } \\
\text { definíció }\end{array}$ & $\begin{array}{l}\text { Új vagy jelentósen javított termék (áru, szolgáltatás) vagy eljárás, új marketingmódszer vagy új szervezési- } \\
\text { szervezeti módszer bevezetése az üzleti gyakorlatba, munkahelyi szervezetbe vagy a külsó kapcsolatokba. } \\
\text { Továbbá: „Az innováció olyan célirányos, szakszerú, intenzív fejlesztő tevékenység, amely többek között a } \\
\text { termék (szolgáltatás), a technológia, a múködés, a szervezet többé-kevésbé átfogó megújulását eredményezi. } \\
\text { Kiindulópontja az új lehetóség felismerése, végpontja pedig a sikeres megvalósítás.” }\end{array}$ \\
\hline Számviteli törvény & Nem tartalmazza. \\
\hline
\end{tabular}

(Forrás: saját szerkesztés)

\section{A ,kutatás-fejlesztés” fogalmai}

\section{KUTATÁS-FEJLESZTÉS}

2004/CXXXIV. törvény

a kutatás-fejlesztésról és a technológiai innovációról

\begin{tabular}{l|} 
NIH fogalomtár \\
KTI ALAP támok, \\
146/2007 rendelet
\end{tabular}

KSH módszertani definíció

Számviteli törvény

(Forrás: saját szerkesztés)
Magában foglalja az alapkutatást, az alkalmazott kutatást és a kísérleti fejlesztést. Magában foglalja az alapkutatást, az alkalmazott kutatást és a kísérleti fejlesztést.

Az Atv. 12. §-ának b) pontjában meghatározott kutatás-fejlesztés (a továbbiakban: K+F); magában foglalja az alapkutatást, az alkalmazott kutatást és a kísérleti fejlesztést.

Olyan módszeresen folytatott alkotómunkát jelent, amely a meglévő ismeretanyag bóvítésére beleértve az emberról, a kultúráról és a társadalomról szerzett ismereteket is -, valamint arra szolgál, hogy ezt az ismeretanyagot új alkalmazások kidolgozására használják fel. A kutatás és kísérleti fejlesztés jellemzói: az alkotás és az újdonság eleme; a tudományos módszerek alkalmazása; új ismeret létrehozása. Típusai: az alapkutatás, az alkalmazott kutatás és a kísérleti fejlesztés.

Nem határozza meg.

\section{Az ,alapkutatás” fogalmai}

\section{ALAPKUTATÁS}

2004/CXXXIV. törvény a kutatás-fejlesztésról és a technológiai innovációról

\section{NIH fogalomtár}

KTI ALAP támok, 146/2007 rendelet

\section{KSH módszertani defi-} níció

Számviteli törvény

(Forrás: saját szerkesztés)

\section{Alapkutatás: elsődlegesen a jelenségek lényegére és a megfigyelhető tényekre vonatkozó tudományos} ismeretek bővítését célzó kísérleti, tapasztalati, rendszerezó vagy elméleti munka, amely lehet aa) tiszta alapkutatás

ab) célzott alapkutatás

Kísérleti vagy elméleti munka, amelyet elsôsorban a jelenségek vagy megfigyelhetô tények hátterével kapcsolatos új ismeretek megszerzésének érdekében folytatnak, anélkül, hogy kilátásba helyeznék azok gyakorlati alkalmazását vagy felhasználását.

A Kutatási és Technológiai Innovációs Alapról szóló 2003. évi XC. törvény (a továbbiakban: Atv.) 12. §-ának a) pontjában meghatározott alapkutatás; az általános tudományos és technikai tudásanyag bóvítése, amely nem kapcsolódik ipari vagy kereskedelmi célkitűzéshez.

Alapkutatás olyan kísérleti és elméleti munka, amelynek elsôdleges célja új ismeretek szerzése a jelenségek alapvetô lényegérôl és a megfigyelhető tényekről, bármiféle konkrét alkalmazási vagy felhasználási célkitüzés nélkül. Két csoportra bontható: tiszta alapkutatás, célzott alapkutatás.

Olyan kísérleti és elméleti munka, amelynek elsődleges célja új ismeretek szerzése a jelenségek alapvető lényegérơl és a megfigyelhetô tényekról, bármiféle konkrét alkalmazási és felhasználási célkitúzés nélkül.

\section{VEZETÉSTUDOMÁNY}




\section{A ,K+F+I eredmények hasznosítása” fogalmai}

\begin{tabular}{|c|c|}
\hline \multicolumn{2}{|r|}{ K+F ÉS I EREDMÉNYEK HASZNOSÍTÁSA } \\
\hline $\begin{array}{l}\text { 2004/CXXXIV. törvény } \\
\text { a kutatás-fejlesztésról és a } \\
\text { technológiai innovációról }\end{array}$ & $\begin{array}{l}\text { Idetartozik mind a vállalkozások keretében, üzleti céllal, gazdasági eredmény reményében } \\
\text { történó felhasználás, mind az olyan közösségi célú felhasználás, amelynek eredménye a lakosság } \\
\text { életminőségének és a közszolgáltatások minőségének javítása, a természeti és épített környezet védelme, } \\
\text { az ország fenntartható fejlődése, valamint védelmi képességének és biztonsági helyzetének javítása. }\end{array}$ \\
\hline NIH fogalomtár & $\begin{array}{l}\text { Hasznosítás (a kutatás-fejlesztési és technológiai innovációs eredmények hasznosítása): idetartozik } \\
\text { mind a vállalkozások keretében, üzleti céllal, gazdasági eredmény reményében történó felhasználás, } \\
\text { mind az olyan közösségi célú felhasználás, amelynek eredménye a lakosság életminôségének és } \\
\text { a közszolgáltatások minőségének javítása, a természeti és épített környezet védelme, az ország } \\
\text { fenntartható fejlődése, valamint védelmi képességének és biztonsági helyzetének javítása (a } \\
\text { továbbiakban: hasznosítás). }\end{array}$ \\
\hline $\begin{array}{l}\text { KTI ALAP támok, } \\
\text { 146/2007 rendelet }\end{array}$ & Nem szerepel benne ez a definíció. \\
\hline $\begin{array}{l}\text { KSH módszertani defi- } \\
\text { níció }\end{array}$ & Nem szerepel. \\
\hline Számviteli törvény & $\begin{array}{l}\text { Önálló definícióként nem szerepel. „A kísérleti fejlesztés aktivált értékeként a jövőben hasznosítható, } \\
\text { a kísérleti fejlesztés eredményének jövőbeni hasznosításakor az árbevételben megtérülő, a kísérleti } \\
\text { fejlesztés eredménye érdekében felmerült olyan számlázott összeget és a saját tevékenység során } \\
\text { felmerült - az 51. § szerinti - közvetlen önköltségbe tartozó költségeket lehet figyelembe venni, } \\
\text { amelyek aktiválható termékben - szellemi termék, tárgyi eszköz, készlet - nem vehetők számításba, } \\
\text { mivel a létrehozott termék piaci - várható piaci - árát meghaladják. A kísérleti fejlesztés állományba } \\
\text { vett aktivált értéke nem haladhatja meg azt az összeget, ami várhatóan megtérül a kapcsolódó jövoobeni } \\
\text { gazdasági haszonból a további fejlesztési költségek, a várható termelési költségek, illetve a termék } \\
\text { értékesítése során közvetlenül felmerülő értékesítési költségek levonása után.” }\end{array}$ \\
\hline
\end{tabular}

(Forrás: saját szerkesztés)

Az alapkutatás valamennyi szabályozó által meghatározott. Ennek oka az egyes kategóriák közötti szabályozottságban keresendó, vagyis a $\mathrm{K}+\mathrm{F}$ alapkategóriáinak meglévő leírásában. Ugyanakkor megállapítható, hogy miközben az egyes definíciók tartalma igen erósen megfeleltethető egymásnak, a szöveges leírás különbözősége nem támogatja az egyértelmú kategóriaképzést.

A következő fogalmak a tiszta alapkutatás, a célzott alapkutatás, az ipari vagy alkalmazott kutatás, valamint a kísérleti (prekompetitív) fejlesztés. Megjegyezzük, hogy e fogalmak áttekintésénél a fent említett körülménnyel szembesülünk. Vagyis azzal, hogy az egyes szabályozók törekszenek a precíz fogalommeghatározásra, egyértelmú tartalmi pontosításra, nagy hangsúlyt fektetnek az egyes kategóriák mind pontosabb elhatárolására, elsősorban a támogatások és ösztönzôk okán. Emellett azonban az egyes definíciók azonosságát nem állapíthatjuk meg.

Megjegyezzük továbbá, hogy a számviteli törvény nem tesz említést az alapkutatás két kategóriájáról, amely a többi szabályozó által elkülönített (8. táblázat).

A „hasznosítás” meghatározásában a 2004. évi CXXXIV. a kutatás-fejlesztésról és a technológiai innovációról szóló törvény és a NIH fogalomtár egyezőséget mutat. A számviteli törvény szempontjából a hasznosítás az elszámolhatóság kérdéseire terjed ki, míg a tartalmi elemek vonatkozásában az elóbbiek az irányadóak. A fogalom ezekben a dokumentumokban igen tágan értelmezett, ami megfelel az innováció fogalmi kiterjesztése irányába mutató nemzetközi trendeknek (9. táblázat).

Érdekessége miatt mutatjuk be a termékinnovációra vonatkozó összegzó, 10. táblázatunkat. Az innováció megjelenési formái közül a 2004. évi CXXXIV. a kutatás-fejlesztésról és a technológiai innovációról szóló törvény nem foglalkozik a termék-, illetve szolgáltatásinnováció kategóriájával - definíciós szinten. Azonban az innováció valamennyi meghatározó megjelenési formája jelen van ebben a szabályozóban.

A technológiai és az eljárásinnováció vonatkozásában megállapítható, hogy a 2004. évi CXXXIV. a kutatás-fejlesztésról és a technológiai innovációról szóló törvény, valamint a NIH fogalomtár azonos módon fogalmaznak. Ezek a megfogalmazások azonban nem esnek egybe sem a KTI ALAP t ámok, sem a KSH definíciótárában foglaltakkal. A számviteli törvény egyik innovációfajtára sem ad meghatározást.

Jól látható azonban, hogy a technológia értelmezése a nemzetközi gyakorlatnak megfelelő módon szerepel a megfogalmazásokban. 
A ,termék- (áru vagy szolgáltatás) innováció” fogalmai

\section{TERMÉK- (ÁRU VAGY SZOLGÁLTATÁS) INNOVÁCIÓ}

\begin{tabular}{|l|l|}
\hline $\begin{array}{l}\text { 2004/CXXXIV. törvény } \\
\text { a kutatás-fejlesztésról és a } \\
\text { technológiai innovációról }\end{array}$ & Nem határozza meg ezt a fogalmat. \\
\hline NIH fogalomtár & $\begin{array}{l}\text { Termékinnováció: olyan áru vagy szolgáltatás bevezetése, mely - annak tulajdonságai és rendeltetése } \\
\text { vonatkozásában - új, vagy jelentôsen megújított. Ez magában foglalja a fejlesztésre vonatkozó } \\
\text { részletes múszaki leírásokat, az összetevóket és anyagokat, a beépített szoftvert, a felhasználóbarát } \\
\text { jelleget, vagy más funkcionális tulajdonságokat. }\end{array}$ \\
\hline $\begin{array}{l}\text { KTI ALAP támok } \\
\mathbf{1 4 6 / 2 0 0 7} \text { rendelet }\end{array}$ & $\begin{array}{l}\text { Új, vagy jelentős mértékben javított termelési vagy szolgáltatási módszer alkalmazása, ideértve a } \\
\text { technikákban, felszerelésekben vagy szoftverekben végrehajtott jelentôs változtatásokat is. }\end{array}$ \\
\hline $\begin{array}{l}\text { KSH módszertani } \\
\text { definíció }\end{array}$ & $\begin{array}{l}\text { Egy új, illetve minóségi, múszaki jellemzói alapján jelentósen továbbfejlesztett áru vagy } \\
\text { szolgáltatás (például egy továbbfejlesztett szoftver, alkatrész vagy alrendszer, a termék/szolgáltatás } \\
\text { felhasználóbarát tulajdonságainak jelentős javítását követó) forgalomba hozatala. Az innovációnak } \\
\text { (újításnak, továbbfejlesztésnek) a vállalkozás számára újnak kell lennie, ugyanakkor nem kell } \\
\text { szükségszerúen az ágazatban vagy a piacon is újdonságnak számítania. Annak nincs jelentósége, hogy } \\
\text { az innovációt eredetileg ki fejlesztette ki. }\end{array}$ \\
\hline Számviteli törvény & Nem szerepel. \\
\hline
\end{tabular}

A technológiai és az eljárásinnováció közötti elhatárolási nehézségek a leírásokban is tükröződnek (12. és 13. táblázat).

A szervezeti és a szervezési innovációk szabályozókban történô megjelenése az innováció újabb területének elismerését jelentette. A két innovációtípus elhatárolásának problematikája azonban jól érzékelhetô a két táblázat összeolvasásakor (14. táblázat).

A marketinginnováció fogalmait a teljesség kedvéért mutatjuk be. Látható, hogy az eltérô szabályozók elté- rô módon kezelik a fogalmat. Amíg például a „mérés”, vagyis a statisztika oldaláról a fogalom definiálására jelentốs hangsúly fordítódott, addig a többi vizsgálatba vont szabályozónál ez nem mondható el.

Figyelemre méltó, hogy sem a 2004. évi CXXXIV. a kutatás-fejlesztésról és a technológiai innovációról szóló törvény, sem a KTI LAP támok rendelet nem tartalmazza a fogalmat.

\section{A technológiai innováció fogalmai}

\section{TECHNOLÓGIAI INNOVÁCIÓ}

\begin{tabular}{|l|l|}
\hline \multicolumn{2}{|c|}{ TECHNOLÓGIAI INNOVÁCIÓ } \\
\hline $\begin{array}{l}\text { 2004/CXXXIV. törvény } \\
\text { a kutatás-fejlesztésról és a } \\
\text { technológiai innovációról }\end{array}$ & $\begin{array}{l}\text { A gazdasági tevékenység hatékonyságának, jövedelmezóségének javítása, illetve kedvezó társadalmi } \\
\text { és környezeti hatások elérése érdekében végzett tudományos, múszaki, szervezési, gazdálkodási, } \\
\text { kereskedelmi múveletek összessége, amelyek eredményeként új, vagy lényegesen módosított } \\
\text { termékek, eljárások, szolgáltatások jönnek létre, új, vagy lényegesen módosított eljárások, } \\
\text { technológiák alkalmazására, piaci bevezetésére kerül sor, beleértve azokat a változásokat, amelyek } \\
\text { csak adott ágazatban vagy adott szervezetnél minósülnek újdonságnak. }\end{array}$ \\
\hline NIH fogalomtár & $\begin{array}{l}\text { Technológiai innováció: a gazdasági tevékenység hatékonyságának, jövedelmezóségének javítása, } \\
\text { illetve kedvezó társadalmi és környezeti hatások elérése érdekében végzett tudományos, múszaki, } \\
\text { szervezési, gazdálkodási, kereskedelmi múveletek összessége, amelyek eredményeként új, vagy } \\
\text { lényegesen módosított termékek, eljárások, szolgáltatások jönnek létre, új, vagy lényegesen módosított } \\
\text { eljárások, technológiák alkalmazására, piaci bevezetésére kerül sor, beleértve azokat a változásokat, } \\
\text { amelyek csak adott ágazatban vagy adott szervezetnél minósülnek újdonságnak. }\end{array}$ \\
\hline $\begin{array}{l}\text { KTI ALAP támok, } \\
\text { 146/2007 rendelet }\end{array}$ & $\begin{array}{l}\text { Az Atv. 12. §-ának e) pontjában meghatározott technológiai innováció; ,,minden olyan tudományos, } \\
\text { múszaki, szervezeti, pénzügyi és kereskedelmi jellegú tevékenység, beleértve az új ismeretanyagba } \\
\text { történó befektetéseket is, amely ténylegesen vagy szándék szerint múszakilag új vagy továbbfejlesztett } \\
\text { termékek, eljárások és szolgáltatások megvalósításához vezet.” }\end{array}$ \\
\hline $\begin{array}{l}\text { KSH módszertani } \\
\text { definíció }\end{array}$ & Nem szerepel, csak eljárásinnováció került megkülönböztetésre. \\
\hline Számviteli törvény & Nem szerepel. \\
\hline
\end{tabular}


Az ,eljárás-innováció” fogalmai

\section{ELJÁRÁSINNOVÁCIÓ}

\begin{tabular}{|c|c|}
\hline $\begin{array}{l}\text { 2004/CXXXIV. törvény } \\
\text { a kutatás-fejlesztésról és a } \\
\text { technológiai innovációról }\end{array}$ & Külön nem szerepel, a kísérleti fejlesztés, technológiai innováció fogalmán belül említi az eljárásokat. \\
\hline NIH fogalomtár & $\begin{array}{l}\text { Új, vagy jelentôs mértékben javított termelési vagy szolgáltatási módszer alkalmazása (ideértve a } \\
\text { technikákban, felszerelésekben és/vagy szoftverekben végrehajtott jelentốs változtatásokat is). } \\
\text { Nem minősülnek innovációnak a következók: kisebb változtatások vagy fejlesztések; a termelési } \\
\text { vagy szolgáltatási képességek növelése olyan gyártási vagy logisztikai rendszerek hozzáadása révén, } \\
\text { amelyek nagyban hasonlítanak a már használatban lévőkhöz; egy eljárás használatának befejezése; } \\
\text { az egyszerú tốkepótlás vagy tốkenövelés; a kizárólag az értékesítési árak megváltozásához köthetố } \\
\text { változások; az egyedi igényekhez igazítás; a rendes szezonális és ciklikus változások, valamint az új, } \\
\text { vagy jelentősen továbbfejlesztett termékekkel folytatott kereskedelem. }\end{array}$ \\
\hline $\begin{array}{l}\text { KTI ALAP támok, } \\
\text { 146/2007 rendelet }\end{array}$ & $\begin{array}{l}\text { Eljárási innováció: új, vagy jelentős mértékben javított termelési vagy szolgáltatási módszer } \\
\text { alkalmazása, ideértve a technikákban, felszerelésekben vagy szoftverekben végrehajtott jelentős } \\
\text { változtatásokat is. }\end{array}$ \\
\hline $\begin{array}{l}\text { KSH módszertani defi- } \\
\text { níció }\end{array}$ & $\begin{array}{l}\text { Egy új, vagy jelentôsen továbbfejlesztett termelési folyamat, forgalmazási módszer, vagy az árukat, } \\
\text { illetve szolgáltatásokat támogató tevékenység bevezetését jelenti. Az innovációnak (újítás vagy } \\
\text { továbbfejlesztés) a vállalkozás számára újnak kell lennie, ugyanakkor nem kell szükségszerúen az } \\
\text { ágazatban vagy a piacon is újdonságnak számítania. Annak nincs jelentôsége, hogy az innovációt } \\
\text { eredetileg ki fejlesztette ki. Nem tartoznak ide a pusztán szervezeti jellegú innovációk. }\end{array}$ \\
\hline Számviteli törvény & Nem szerepel. \\
\hline
\end{tabular}

(Forrás: saját szerkesztés)

\section{A ,szervezeti innováció” fogalmai}

\begin{tabular}{|c|c|}
\hline \multicolumn{2}{|r|}{ SZERVEZETI INNOVÁCIÓ } \\
\hline $\begin{array}{l}\text { 2004/CXXXIV. törvény } \\
\text { a kutatás-fejlesztésról és a } \\
\text { technológiai innovációról }\end{array}$ & $\begin{array}{l}\text { Olyan új szervezési módszerek bevezetését jelenti, amelyeket a vállalat üzleti gyakorlatában (ideértve } \\
\text { a tudásmenedzsmentet is), munkahelyi szervezetében vagy külső kapcsolataiban alkalmaznak, } \\
\text { és amelyek korábban nem voltak a vállalatnál alkalmazásban. Szükséges feltétel továbbá, hogy } \\
\text { az ilyen lépéseknek a vezetőség stratégiai döntéseinek eredményeképpen kell megvalósulnia. Az } \\
\text { egyesülések vagy kivásárlások nem sorolandók ide, még akkor sem, ha először fordulnak elő a vállalat } \\
\text { történetében. }\end{array}$ \\
\hline NIH fogalomtár & $\begin{array}{l}\text { Új, vagy jelentős mértékben javított termelési vagy szolgáltatási módszer alkalmazása (ideértve a } \\
\text { technikákban, felszerelésekben és/vagy szoftverekben végrehajtott jelentős változtatásokat is). Nem } \\
\text { minősülnek innovációnak a következók: kisebb változtatások vagy fejlesztések; a termelési vagy } \\
\text { szolgáltatási képességek növelése olyan gyártási vagy logisztikai rendszerek hozzáadása révén, } \\
\text { amelyek nagyban hasonlítanak a már használatban lévőkhöz; egy eljárás használatának befejezése; } \\
\text { az egyszerú tókepótlás vagy tókenövelés; a kizárólag az értékesítési árak megváltozásához köthetố } \\
\text { változások; az egyedi igényekhez igazítás; a rendes szezonális és ciklikus változások, valamint az új, } \\
\text { vagy jelentôsen továbbfejlesztett termékekkel folytatott kereskedelem. }\end{array}$ \\
\hline $\begin{array}{l}\text { KTI ALAP támok, } \\
\text { 146/2007 rendelet }\end{array}$ & Nem szerepel. \\
\hline $\begin{array}{l}\text { KSH módszertani } \\
\text { definíció }\end{array}$ & $\begin{array}{l}\text { Olyan új szervezési módszerek bevezetését jelenti, amelyeket a vállalat üzleti gyakorlatában (ideértve } \\
\text { a tudásmenedzsmentet is), munkahelyi szervezetében vagy külső kapcsolataiban alkalmaznak, } \\
\text { és amelyek korábban nem voltak a vállalatnál alkalmazásban. Szükséges feltétel továbbá, hogy } \\
\text { az ilyen lépéseknek a vezetőség stratégiai döntéseinek eredményeképpen kell megvalósulnia. Az } \\
\text { egyesülések vagy kivásárlások nem sorolandók ide, még akkor sem, ha először fordulnak eló a vállalat } \\
\text { történetében. }\end{array}$ \\
\hline Számviteli törvény & Nem szerepel. \\
\hline
\end{tabular}

(Forrás: saját szerkesztés) 


\section{A,„Szervezési innováció” fogalmai}

\section{SZERVEZÉSI INNOVÁCIÓ}

\begin{tabular}{|l|l|}
$\begin{array}{l}\text { 2004/CXXXIV. törvény } \\
\text { a kutatás-fejlesztésról és a } \\
\text { technológiai innovációról }\end{array}$ & Külön nem szerepel, a technológiai innováció tárgyalásánál kerül feltüntetésre a felsorolásban. \\
\hline NIH fogalomtár & $\begin{array}{l}\text { Új szervezési módszer alkalmazása a vállalkozás üzleti gyakorlataiban, munkahelyi szervezetében } \\
\text { vagy külsó kapcsolataiban. Nem minósül innovációnak az üzleti gyakorlatokban, a munkahelyi } \\
\text { szervezetben vagy külső kapcsolatokban eszközölt olyan változtatás, amely a vállalkozáson belül már } \\
\text { alkalmazott szervezési módszereken alapul, a vezetési stratégia megváltoztatása, a fúzió és felvásárlás, } \\
\text { egy eljárás alkalmazásának beszüntetése, az egyszerú tókepótlás vagy tốkenövelés, a kizárólag az } \\
\text { értékesítési árak megváltozásához köthetó változás, az egyedi igényekhez igazítás, a rendes szezonális } \\
\text { és egyéb ciklikus változás, az új, vagy jelentósen továbbfejlesztett termékkel folytatott kereskedelem. }\end{array}$ \\
\hline $\begin{array}{l}\text { KTI ALAP támok, } \\
\text { 146/2007 rendelet }\end{array}$ & $\begin{array}{l}\text { Szervezési innováció: új szervezési módszer alkalmazása a vállalkozás üzleti gyakorlatában, } \\
\text { munkahelyi szervezetében vagy külsó kapcsolataiban. }\end{array}$ \\
\hline $\begin{array}{l}\text { KSH módszertani } \\
\text { definíció }\end{array}$ & $\begin{array}{l}\text { „Szervezeti-szervezési innováción az olyan új szervezési módszerek bevezetését értjük, amelyeket a } \\
\text { válalat üzleti gyakorlatában (ideértve a tudásmenedzsmentet is), munkahelyi szervezetében vagy külsó } \\
\text { kapcsolataiban alkalmaznak, és amelyek korábban nem voltak a vállalatnál alkalmazásban. Szükséges } \\
\text { feltétel továbbá, hogy az ilyen lépéseknek a vezetóség stratégiai döntéseinek eredményeképpen kell } \\
\text { megvalósulnia. Az egyesülések vagy kivásárlások nem sorolandók ide, még akkor sem, ha először } \\
\text { fordulnak eló a vállalat történetében.” }\end{array}$ \\
\hline Számviteli törvény & \begin{tabular}{l} 
Nem szerepel. \\
\hline
\end{tabular}
\end{tabular}

(Forrás: saját szerkesztés)

A ,marketinginnováció” fogalmai

MARKETINGINNOVÁCIÓ

\section{4/CXXXIV. törvény}

a kutatás-fejlesztésról és a technológiai innovációról

\section{NIH fogalomtár}

KTI ALAP támok, 146/2007 rendelet

KSH módszertani definíció
Nem szerepel.

Olyan új marketingmódszerek alkalmazása, amelyek jelentős változást hoznak a terméktervezésben, a csomagolásban, a termék pozicionálásában, a termék reklámozásában vagy az árképzésben.

Nem szerepel.

Olyan új marketingmódszer bevezetése, amelyet a vállalat korábban még nem használt, azaz jelentôs változások végrehajtása a termék formaterve vagy csomagolása, elhelyezése, reklámozása vagy árkialakítása területein. Az új módszer bevezetése egy olyan új marketingkoncepciónak vagy stratégiának kell, hogy része legyen, amely lényegesen különbözik a vállalat meglévő marketingmódszereitől. Nem tartoznak ide a marketingmódszerek évszakokhoz igazodó, rendszeres és egyéb rutinváltozásai.

Nem szerepel.

(Forrás: saját szerkesztés)

Az innováció mint „tevékenység” fogalmait áttekintve a következő összegzést tehetjük:

- jól látható, hogy a szabályozásban megjelentek az innováció $\mathrm{K}+\mathrm{F}$-en túlmutató elemei,

- az egyes szabályozók közötti összehangolás részlegesnek tekinthető,

- az innováció eredményeinek statisztikai összegzését a tervezési, forrásteremtési szabályozás és a KSH eltérố terminológiái is nehezítik,

- a marketinginnováció definicióhiányai elgondolkodtatóak,
- a szervezeti és a szervezési innováció közötti határok meghúzása mind az elméleti, mind pedig a gyakorlati vonatkozásokban nehéz, esetenként lehetetlen, és ez a fogalmi elhatárolásokban is tükröződik,

- a számviteli adatok közvetlen módon nem adnak támogatást az innovációs eredmények számbavételéhez. Így ezek az információk torzítva jelennek meg a KSH által közzétett adatokban. A mérés tehát megvalósul, miközben a kapott eredmények megbízhatósága nehezíti a mindenkori innovációpolitika tervezését és értékelését. 
A cikk egyes fejezeteiben megfogalmazott megállapításainkon túl összegzésül annyit kívánunk mondani, hogy a szabályozók innováció fogalomrendszerének definiálása fokozatosan valósul meg. Kutatásunk tisztázó jellege iránytúként szolgálhat a gazdasági szakemberek számára, valamint figyelemfelhívásként a jogszabályalkotók felé. A gyakorlatban tapasztalható fogalmi illesztettlenségek megszüntetése mind a korrekt értelmezés elérését, mind pedig a mérés bizonytalanságának megszüntetését eredményezné.

\section{Felhasznált irodalom}

Balogh T. (2007): Kutatás-fejlesztési stratégiánk kérdései (előadás). GKM Innovációs és K+F Főosztály, 2007. június 6 .

Buzás N. (szerk.) (2007): Innovációmenedzsment a gyakorlatban. Budapest: Akadémiai Kiadó

Drucker, P. F. (2003.): Az innováció lehetőségei. Harvard Businessmanager. 2003. május-június. 28-34. o.

Haryson, R.T. - Sigvald, J. (1998): Japanese Technology and Innovation Management. London: Edward Elgar

Iványi A. Sz. - Hoffer I. (2011): Innováció a vállalkozásfejlesztésben. Budapest: Aula Kiadó

OECD (2002): Frascati Kézikönyv: Javaslat a kutatás és kísérleti fejlesztés felméréseinek egységes gyakorlatára OECD (2005): Oslo Manual

Pearce, D. W. (szerk.) (1993): A modern közgazdaságtan ismerettára. Budapest: Közgazdasági és Jogi Könyvkiadó

Pietrasinski, Z. (1997): Alkotó vezetés. Budapest: Gondolat Kiadó

Prahalad, C. K. (2009): Új menedzsment-paradigmák felé Budapest: Alinea Kiadó - Rajk László Szakkollégium

Schumpeter, J.A. (1939): Business Cycles. New York: McGraw-Hill

Szakály D. (2008): Innovációmenedzsment. Miskolc: Miskolci Egyetem, Gazdaságtudományi Kar

Trott, P. (1998): Innovation Management and New Product Development. London: Financial Times Management Pitman Publishing

Trott, P. (2004): Innovation Management and Product Development. 3rd edition. Essex: Pearson Education

\section{Jogszabályok:}

- 146/2007. (VI. 26.) Korm. rendelet a Kutatási és Technológiai Innovációs Alapból nyújtott állami támogatások szabályairól

http://net.jogtar.hu/jr/gen/hjegy_doc.cgi?docid= A0700146.KOR

- 2000. évi C. törvény a számvitelról

http://net.jogtar.hu/jr/gen/hjegy_doc.cgi?docid= A0000100.tv

- 2004. évi CXXXIV. törvény a kutatás-fejlesztésról és a technológiai innovációról

http://net.jogtar.hu/jr/gen/hjegy_doc.cgi?docid= A0400134. tv

- 2003. évi XC. törvény a Kutatási és Technológiai Innovációs Alapról

http://net.jogtar.hu/jr/gen/hjegy_doc.cgi?docid= A0300090.tv

- Nemzeti Innovációs Hivatal Fogalmak http://www.nih.gov.hu/ugyfelszolgalat/fogalomtar

- KSH kutatás-fejlesztés fogalmak http://www.ksh.hu/pls/ksh/ksh_web.meta.objektum?p_ lang=HU\&p_menu_id=110\&p_almenu_id=102\&p_ot_ $\mathrm{id}=100 \&$ p_obj_id=OHK\&p_session_id=41337299\&p_ nav=Fogalmai

- KSH innovációs fogalmak http://www.ksh.hu/pls/ksh/ksh_web.meta.objektum?p_ lang=HU\&p_menu_id=210\&p_almenu_id=201\&p_ot_ $\mathrm{id}=200 \&$ p_level=6\&p_session_id=57951809\&p_obj_ $\mathrm{id}=4698$

- A BIZOTTSÁG 800/2008/EK RENDELETE (2008. augusztus 6.) a Szerződés 87 . és 88 . cikke alkalmazásában a támogatások bizonyos fajtáinak a közös piaccal összeegyeztethetőnek nyilvánításáról (általános csoportmentességi rendelet) (EGT-vonatkozású szöveg) http://eur-lex.europa.eu/LexUriServ/LexUriServ.do?uri= OJ:L:2008:214:0003:0047:hu:PDF

- 14/2011. (III. 4.) NFM utasítás a Kutatási és Technológiai Innovációs Alap kezelésének és gazdálkodásának szabályairól

http://www.complex.hu/jr/gen/hjegy_doc.cgi?docid= A11U0014.NFM

Cikk beérkezett: 2011.10. hó

Lektori vélemény alapján véglegesítve: 2011. 11. hó 